
\title{
Repeal of embryo law urged after child's cure
}

Federica Castellani

On 6 September, Italy's health minister hailed the successful treatment of a sick child with 'adult' stem cells from newborn siblings. He was hoping to strengthen the government's position that embryonic manipulation is not required for medical progress.

But the minister's declaration rebounded on him the next day, when it emerged that the treatment was only made possible by in vitro fertilization of the child's mother in Turkey - using an embryo selection technique that the Italian government outlawed in February.

Now the health minister, Girolamo Sirchia, is facing calls for his resignation, and campaigners are hoping to overturn the law against embryo selection in a referendum, which could be held next summer.

The five-year-old child was treated for thalassaemia, a hereditary blood disease that causes life-threatening anaemia. Doctors cured him by using adult stem cells derived from the umbilical cord blood of twin siblings, borne by his mother.

The parents originally wanted to use cord blood from their next, healthy child, but the blood proved incompatible with their ill son's immune system. So they underwent in vitro fertilization in Istanbul, where 12 embryos were created and tested for the presence of the thalassaemia gene and immunological compatibility. Three healthy and compatible embryos were selected for implantation, and twins were born in April.

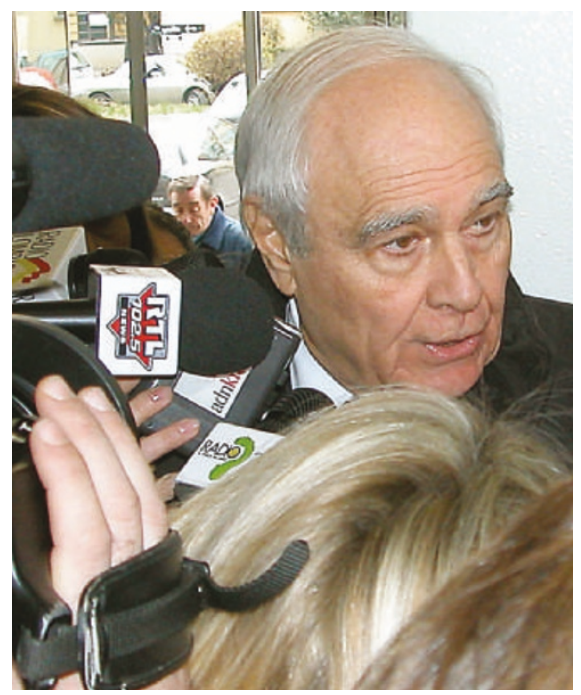

Girolamo Sirchia: the Italian health minister's gaffe has provoked calls for his resignation.

The boy was treated in Pavia in August. During a visit to the Milan clinic where the cord stem cells were manipulated before implantation, Sirchia told journalists: "This is a historical result, which awakens hopes."

But Italy's law on assisted reproduction bans the testing of embryos for genetic disease, as well as restricting the number of embryos that may be generated for in vitro fertilization to three. Now opponents of the law are taking this chance to push for its repeal.

A few days after the law was passed, the minority Radical party launched a petition for a referendum on whether it should be revoked. The campaign has struggled to collect the 500,000 signatures that would be required before the end of September to oblige the government to hold such a vote next summer. "But this case has given a real boost to the campaign," says Cinzia Caporale, a bioethicist from Rome who opposes the law. "It probably guarantees that the right number of signatures will now be collected."

Sirchia says the campaigners are distorting events for political ends. "The cure of the child and the in vitro selection of healthy embryos are not correlated," he says. But scientists point out that, without embryonic selection, the chance of producing an immunologically compatible child who did not have the disease gene would have been less than one in five. Several parliamentarians have called for Sirchia's resignation.

Amid fears that a referendum could threaten the law, a wide spectrum of politicians are trying to negotiate a compromise. Two members of Forza Italia, the party of Prime Minister Silvio Berlusconi, have called for a parliamentary debate about possible amendments on 22 September.

But Francesco D'Agostino, a philosopher at Tor Vergata University in Rome and head of the National Bioethics Committee, which helped formulate the law, is wary. "This specific case is not enough to justify a general law," he says. "To create embryos and destroy those not useful to us is a eugenic practice and we need to think carefully about whether we want eugenics in our law."

\section{NASA probes Genesis wreck in bid to salvage data}

\section{Nicola Jones, London}

The NASA solar-wind probe that crashlanded in the Utah desert last week was cunningly designed to deal with landing problems, mission planners say. But the jury is out on how much data can be saved.

"The prospects for our highest priority objectives are good, although we probably won't be able to do everything we wanted," says Don Burnett, principal investigator on the Genesis project.

The US\$260-million Genesis probe carried delicate wafers of gold, diamond, sapphire and silicon, designed to catch particles from the solar wind. The four plates of these wafers, which were exposed to different kinds of solar activity, were made of slightly different thicknesses. This was intended to help researchers reassemble the plates if a bumpy landing smashed them.

NASA arranged for highly trained helicopter pilots to snag the returning capsule after parachutes had slowed its return to Earth (see Nature 429, 340-342; 2004). Mission planners were fairly confident that damaged plates could be reconstructed if the parachutes worked but the pilots failed, leaving the probe to hit the desert at about 10 kilometres per hour.

Unfortunately, the parachutes themselves failed, and the probe smashed into the ground on 8 September at more than 200 kilometres per hour. "We have a mangled mass of a spacecraft," says David Lindstrom, a Genesis programme scientist based at NASA headquarters in Washington.

Some of the detectors, including a concentrator designed to collect the densest sample of solar wind, seem intact. The impact smashed many of the wafers, however, and also ruptured the container, exposing some, if not all, of the detectors to Earth's air and soil — a much bigger problem for mission scientists.
But they remain optimistic, says Lindstrom. The atoms collected from the solar wind slammed into the detectors at hundreds of kilometres per second, so they should be buried 100-150 nanometres beneath the plate surfaces. It could therefore be possible to distinguish this tiny sample from contamination on the surface.

The mission debris was dug out of the desert and taken to a cleanroom at the Jet Propulsion Laboratory in Pasadena. The Genesis Mishap Investigation Board will try to determine what caused the failure. One possibility is a battery that should have sparked a small explosion to release the parachutes. Another NASA mission, Stardust, is relying on a similar parachute system for its return to Utah in 2006. 